\title{
Teacher-Student Relationships: The Impact on High School Students
}

\author{
Shadrack Agyekum \\ School of Education, Higher Education Administration, Liberty University \\ 1971 University Blvd, Lynchburg, VA 24515, USA
}

\begin{abstract}
Teacher-student relationship is one of the factors that promotes students learning. Positive interaction creates peaceful environment, but negative interaction leads to instability. Teacher's positive relationship helps to promote student's academic growth. Teachers who emphasize positive aspect of students rather than negative aspect helps the students to be more forthcoming with positive behavior. An overemphasized negative students' attitude rather than praise leads to bad relation between instructors and students.
\end{abstract}

Keywords: student and teacher relationship, teacher self-efficacy, discipline strategies

DOI: $10.7176 / \mathrm{JEP} / 10-14-15$

Publication date:May $31^{\text {st }} 2019$

\section{Introduction}

Teacher-student relationship has been identified as an important factor that improves student learning and academic outcome. Teachers play significant role in education by helping students to achieve their goals. Research conducted by Cook et al. (2018) revealed that some students spend enough time with their teachers during the week. Several researchers have attempted to unlock the mystery behind student-teacher relationships quality and academic performance across primary schools (Hughes et al., 2012). Positive teacher-student relationships help students to excel in academics. Negative teacher-student relationship promotes significant problems that can affect the student to the highest level.

Studies have shown that teachers' supportive relationship affects students behavioral and academic adjustment. Academic and behavioral performance can be characterized by high levels of teachers' support which can either improves or deteriorate students' academic outcomes. Several characteristics can influence teacher-student relationship quality. According to Hughes et al. (2008), teachers' behavior can cause students to act in a positive or negative way. Similarly, student's attitudes toward teachers can influence the teacher to act positive or negative towards them.

Research has it that primary school students tend to rely on their teachers for guidance (Cook et al., 2018). However, researchers have identified that as students pass through education, they become adjusted to the system and learn how to regulate their own behavior without the need for guidance from their teachers. Due to this fact, teacher-student relationship may take a new turn in the student's school years. According to Wu and Hughes (2015), teacher-student relationship weakens from early to late elementary school as the student continue to develop. Teachers' sense of belonging may become important as the student progress beyond primary education and transition into high school.

\section{Perspective of Student Teacher Relationships}

There are numerous perspectives regarding teacher-student interactions. According to Ravitch (2010), institutions educate students to become responsible citizens with well-developed mindset (p. 227). The intent of education is to produce researchers, scientists, engineers and many other experts to solve global problems. Students' academic outcomes cannot be achieved if the foundation that holds or bond them is broken. Social relationships define students' intellectual functioning. According to Cazden (2001), responsiveness can be ascertained when students familiarize themselves with their teachers and institution's code of conduct. Institutions create learning environment for students to build affective interpersonal relationship with their teachers. Cazden (2001) added that teacher-student relationship is one of the significant factors in the learning environment. Research conducted by Krane et al. (2017) revealed students develop positive relationship with their teachers when respect is exchanged between teachers and students.

Moreover, negative behavior affects both teachers and students. A deviant student stands the risk of expulsion if the student's actions destabilize the school, teachers, and students. According to Krane et al. (2017), students who disrespect authority may be either sanctioned, expelled or charged. On the other hand, teachers who refuse to obey school rules and regulations are often charged to refrain from immoral acts. Positive teacher-student relationships lead to lasting peace, but negative relationships thus creative hostile environment for both teachers 
and students. High school students are expected to respect school rules and regulations. However, when students disobey school rules, teachers will intervene to ensure the students are bought to book.

\section{Discipline Strategies}

Jong et al. (2014) stressed that unfavorable condition such as provocation may be difficult to control. Conflicts and misunderstanding can harm either students or teachers psychologically. Research has it that teachers who favor positive reinforcement sometimes use punishment to control students. Lewis et al. (2005) added that relationship between coercive discipline strategies, sensitive discipline strategies, and students' misbehavior varies. Coercive discipline distracts students and hardens them than sensitive discipline. On other hand, aggressive discipline strategies do not help students, it rather makes students misbehave more towards teachers. Roache (2011) confirmed that coercive and aggressive punishment affects student's wellbeing and motivation.

\section{Teacher Self-efficacy}

Self-efficacy is about teachers' capacity and skills that are relevant in teaching (Tschannen-Moran, 2001). Selfefficacy predicts teachers' effort and the efforts increases teachers' chance of experiencing mastery. First time teachers' socialization started when they were students. Those who have served before stands the chance of becoming a good teacher. Teachers' knowledge helps them to teach and handle students during class hours. During teaching, teachers are expected to emulate good morals for students to follow. Teachers with high selfefficacy serve institutions in a positive way to meet students' needs. When students' learning outcomes are met, it helps the students to develop positive relationship with their teachers (Jong et al., 2014). Lower self-efficacy teachers relate to poor students' relationships. Morris-Rothchild and Brassard (2006) revealed that teachers with high efficacy support students' growth than those with lower self-efficacy. High Self-efficacy strengths positive teacher-student relationships.

\section{Conclusion}

Teacher-student relationship has been in existence since time immemorial. Across the globe, teachers are expected to relate with their students positively. Educators create lifelong learners and learners' goal cannot be achieved if there is enmity between teachers and students. Vygotsky (1978) stated that higher mental functioning is socially formed and culturally transmitted when teachers engage with students. Other researchers have revealed that cognitive development is enhanced through language dialogue between teachers and students. Teachers can shape students' thinking skills provided the teachers purposefully interact with the students in a positive way. Vygotsky (1978) stressed that teacher-student interactions awakens variety of developmental processes. Students who develops positive relationship with their teachers can overcome many challenges in school. Institutions must help students to work on building positive relationships with their teachers.

\section{References}

Cazden, C. B. (2001). Classroom discourse the language of teaching and learning. Portsmouth, NH: Heinemann.

Cook, C. R., Coco, S., Zhang, Y., Duong, M. T., Renshaw, T. L., Long, A. C., \& Frank, S. (2018). Cultivating positive teacher-student relationships: Preliminary evaluation of the establish-maintain-restore method. School Psychology Review, 47(3), 226-243.

Hughes J. N., Luo, W., Kwok, O., \& Loyd, L. (2008). Teacher-student support, effortful engagement, and achievement: A three-year longitudinal study. Journal of Educational Psychology, 100(1), 1-14.

Hughes, J. N., Wu, J., Kwok, O., Villarreal, V., \& Johnson, A. Y. (2012). Indirect effects of child reports of teacher-student relationship on achievement. Journal of Education Psychology, 104(2), 350-365.

Jong, R., Mainhard, Tim., Tartwijk, J., Veldman, I., Verloop, N., \& Wubbels, T. (2014). How pre-service teachers' personality traits, self-efficacy, and discipline strategies contribute to the teacher-student relationship. British Journal of Educational Psychology, 84(2), 294-310.

Kranea, V., Nessa, O., Holter-Sorensena, N, Karlssona, B., \& Binderb, P. (2017). You notice that there is something positive about going to school: How teachers' kindness can promote positive teacher- student relationships in upper secondary school. International Journal of Adolescence and Youth, 22(4), 377-389.

Lewis, R., Romi, S., Qui, X., \& Katz, Y. J. (2005). Teachers' classroom discipline and student misbehaviour in Australia, China and Israel. Teaching and Teacher Education 21(6):729-741

Morris-Rothschild, B., \& Brassard, M. R. (2006). Teachers' conflict management styles: The role of attachment styles and classroom management efficacy. Journal of School Psychology, 44, 105-121.

Roache, J. E., \& Lewis, R. (2011). The carrot, the stick, or the relationship: What are the effective disciplinary strategies? European Journal of Teacher Education, 34, 233-248.

Tschannen-Moran, M., \& Woolfolk Hoy, A. W. (2001). Teacher efficacy: Capturing an elusive construct. Teaching and Teacher Education, 17, 783-805. 